Synthesis, part of a Special Feature on The Conservation and Restoration of Old Growth in Frequent-fire Forests of the American West

\title{
The Tribal Perspective of Old Growth in Frequent-fire Forests-Its History
}

\author{
Victoria Yazzie $^{1,2}$
}

\begin{abstract}
Anyone who has not lived in "Indian country" cannot understand just how extensively the United States government and its laws affect Native Americans and their natural resource management. These effects are sobering, and touch upon sensitive issues that all Native Americans hold within us. In this article, I outline the historic cycle of tribal entities, and characterize today's tribal self-determination in forest management. I provide an historical account from the "colonial" period and its use of the Doctrine of Discovery to the relations between the United States government and Native Americans from the $18^{\text {th }}$ through the $20^{\text {th }}$ centuries, during which time Native Americans struggled to establish their legal status as tribes, and solidify their land base to sustain and conserve culturally important lands, including areas of old-growth forests, to the current self-determination and self-governance potential of Indian tribes. More importantly, I discuss the cultural connectivity that Native Americans have to the land, and address the unique inherent right of tribes to integrate this cultural view into current forest management, including the protection of old-growth forests, on their reservations.
\end{abstract}

Key Words: Bureau of Indian Affairs; Doctrine of Discovery; indigenous peoples' forest management; Marshall Court; tribal self-determination

\section{INTRODUCTION}

In this chapter, I focus on the history of tribal forest and woodland management, and the tribal perspective of old growth in Indian country, and how extensively the federal government and its laws affect Native Americans and their current natural resource management. Federal Indian law began with the cultural conflicts between Native Americans and European settlers during the early colonial period, and continues to this day to influence Indian law and policy and how tribes manage their resources. By recognizing this beginning, an understanding may unfold about of the divergence of ideas and practices between Native Americans and Europeans-a cultural difference that expressed itself in the Native Americans' use of fire, which created old growth before European invasion, and the rare presence of old-growth forests today, which is due in large part to a European-based idea of resource management without fire.

\section{NATIVE AMERICAN HISTORY BEFORE EUROPEAN INVASION}

Native Americans used fire for hundreds to thousands of years to manage forests and construct old-growth structure before European settlement (Cronon 1983, Delcourt and Delcourt 1997, Anderson 2005). Details of these practices can be generalized from historic records and reconstructions of habitat characteristics before European contact. Although the intent to uncover history validates historic habitat structure, the evidence of Native American influence is minimized or lost through misinterpretation by non-Indian perceptions of American Indian history (Wilson 1996) and the effects of traditional ecological knowledge (TEK) use (Simpson 2004). Native American people have long had an immediate relationship with their physical environment and were cognizant of its rhythms and resources. Their management of natural resources and the altering of landscapes with fire are grounded in generations of accumulated wisdom and a reciprocal obligation with all animals and inanimate beings (TEK; Simpson 2004). 


\section{EUROPEAN COLONIAL PERIOD}

In the $15^{\text {th }}$ century, the race for empire in North America coincided with a rise in the economies of the Netherlands, England, France, and Spain. Each nation was in varying stages of a transition to capitalism, and each was on the threshold of creating a new and more dynamic economy built upon trade strategy. North America and its inhabitants were seen as a means to augment the material ambitions of the invading European powers, and the inhabitants immediately became both pawns and participants in the strategies of the world market.

Colonization in New England began at a time when the ecological conditions of extensive regions of North America depended on prescribed fire use by Native Americans. The ecology of these landscapes began to be changed by European settlers who altered the uses of the land, and by the forced decline of the Native American people and their use of ecological knowledge (Cronon 1983, Stewart 2002). Changing patterns of native resources use by European invasion altered the physical and cultural landscape in this "New World."

To the Europeans, the overall resource abundance of the New World-as evidenced by the old-growth forests, large herds of animals, large flocks of birds - seemed infinite. The fur trade and lumber industries opened the door to resource exploitation. A clause in the 1691 Massachusetts charter describes the fate of old-growth white pine (Pinus strobus) forests: "all [mast] trees of the diameter of twenty-four inches and upward at twelve inches" to be marked for use by the British Royal Navy (Cronon 1983, p. 110). In 1630, 24 sawmills provided white pine ship masts for the British Royal Navy. White pine trees were $61-122 \mathrm{~cm}(2-4 \mathrm{ft})$ in diameter and 36.6-61 m (120-200 ft) tall. Intense lumbering that favored "the richest and straightest" trees was commonplace up to the late- $19^{\text {th }}$ century (Cronon 1983, p. 111).

\section{THE UNITED STATES GOVERNMENT: FEDERAL LAWS AND LEGAL DECISIONS THAT DEFINED NATIVE AMERICANS AND THEIR LANDSCAPES}

Since its inception, the United States government has enacted laws and policies oppressing and marginalizing Native Americans and depriving them of their lands and traditional cultural practices.
These laws, legal decisions, and policies are based on the Doctrine of Discovery, a medieval doctrine that gave property rights to the country that discovered a piece of land. The European countries, and later the United States, used this doctrine to justify imposing unilateral state ownership on indigenous lands and guardianship over indigenous peoples because of their assumed racial and cultural inferiority (Miller 2005).

Race, racism, extermination, and conquest were the driving forces behind the laws pertaining to indigenous people. The Trade and Intercourse Act of 1790 states the ownership and guardianship of indigenous lands and people under the United States government:

No person shall be permitted to carry on any trade or intercourse with the Indian tribes, without a license of that purpose under the hand and seal of ...such...person as the President of the United States shall appoint for that purpose... (Section 1), and

No sale of lands made by any Indians, or any nation or tribe of Indians within the United States, shall be valid to any person or persons, or to any state... unless the same shall be made and duly executed at some public treaty, held under the authority of the United States" (Section 4).

Later, the Non-Intercourse Act of 1793 mirrored and supported the conquest idea in early colonial America:

No purchase, grant, lease, or other conveyance of lands, or of any title or claim thereto, from any Indian nation or tribe of Indians, shall be of any validity in law or equity, unless the same be made by treaty or convention entered into pursuant to the Constitution. (Chapter 19, Section 8, 1 Stat. 329, 330.)

Federal government power over Native Americans and their lands derives from the legislative enactments and judicial decisions during the time of Chief Justice John Marshall (Robertson 2005). In the landmark 1823 case, Johnson v. McIntosh, the United States Supreme Court defined the relationship between the federal government and the tribes by applying the finder's law analysis to the discovering European claim to land title in native 
America. In writing the majority opinion, Chief Justice Marshall indicated that the Indians' right of occupancy could be terminated by the European sovereign and exclusive power to acquire Indian lands by "purchase or conquest" (Johnson v. McIntosh 1823, at 587). The aim was to ensure exclusive right to the discoverer to appropriate the lands occupied by Indians, and that the sovereigns of Europe had granted lands still in possession of Indians (Johnson v. McIntosh 1823, at 584).

The Supreme Court handed down another landmark decision in Cherokee Nation v. Georgia (1831), in which the court ruled that Native American tribes were "domestic dependent nations" of the federal government, with the federal government acting as equals after the Revolutionary War (Pevar 1992). This ruling of tribes as "domestic dependent nations" rather than "foreign states," within the meaning of Article III, Section 2 of the United States Constitution, defines federal judicial power. Tribes were defined as "states," but not considered as "foreign" states, characterizing them as being "in a state of pupilage," whereas before the relationship was defined as one of guardian and ward. The Court denied the Cherokees' request for an injunction against the enforcement of Georgia statute that extended the laws of Georgia over Cherokee land and abolished the laws of the Cherokee Nation.

In Cherokee Nation v. Georgia (1831), the Court's determination created the foundation for today's sovereignty doctrine and self-determination policy (Cross 2003, Yazzie 2006). The sovereignty status of Indian tribes has its basis in the theory of "inherent right" to control the lands within the exterior boundaries of their reservations (Mettler 1978, Getches et al. 1993, Yazzie 2006). Despite this decision, tribes remain engaged in a 500-year struggle to safeguard their lands from outside expropriation and destruction of their natural resources and cultural integrity.

Worchester v. Georgia (1832), the third opinion of the Marshall-led court, described Indian nations as "distinct political communities, having territorial boundaries, within which their authority is exclusive," and excluded the states from power over Indian affairs within those boundaries (Worchester v. Georgia 1832, at 515, 557-61). The Georgia legislature in 1828, enacted legislation to "add the territory within the limits of the state, and occupied by the Cherokee Indians" extending the laws of the state over Cherokee Nation. In 1829, Andrew
Jackson was sworn into office as president of the United States. He urged Congress to adopt legislation to complement Georgia's and Alabama's extension jurisdiction over the Cherokees and the Creeks. Many states followed suit in abrogating Indian lands and rights of occupation to state jurisdiction. Jackson's notion to the tribes was submit to the states or leave! John Marshall was distressed at Congress's cooperation in the coercive measures begun by the states of Georgia, Alabama, and Mississippi and with the strong support of President Jackson. In 1830, President Jackson signed the Indian Removal Act into law. In Worchester v. Georgia, Marshall intended to undo Johnson v. McIntosh, the discovery rule. However, in 1835, with Johnson dead, President Jackson appointed James M. Wayne (a former member of the Georgia Supreme Court) as Chief Justice. The Johnson discovery rule was restored, and Indian tribes ceded all the lands east of the Mississippi River in exchange for fee lands west of the Mississippi River.

In 1789, the United States Congress placed Native American relations within the War Department, and by 1806 , Congress created a Superintendent of Indian Trade, who was charged with maintaining the factory trading network of the fur trade. With the abolition of the factory system in 1822, the Secretary of War John C. Calhoun formed and created on 11 March 1824 the current Bureau of Indian Affairs (BIA), without authorization from the United States Congress. In 1849, the "Indian Office" was transferred to the Department of the Interior, and renamed the Bureau of Indian Affairs in 1947 from the original Office of Indian Affairs. The BIA is an agency of the federal government of the United States within the Department of the Interior charged with the administration and management of land held in trust by the United States for American Indians, Indian tribes, and Alaska Natives.

Federal Indian policy changed between 1825 and the 1850s. The federal government began openly discussing moving all tribes west of the Mississippi River-a dialogue that resulted in the Indian Removal Act of 1830, which was signed by President Andrew Jackson. During the 1830s, many tribes were forcibly marched to "Indian Territory" in Oklahoma (Cherokee "Trail of Tears"). The federal policy to slowly and methodically remove all tribes to the Indian Territory was overwhelmed by the opening of the Oregon Trail in the early 
1840s, and the discovery of gold in California in 1849. Vast areas of the American West were now "up for grabs" (Cross 2003). In Louisiana, the Southwest, and the Northwest, the federal government purchased or acquired the land from foreign powers in preparation for western settlement and the creation of territories. Tribal title west of the Mississippi River had to be extinguished so that the property rights of future private non-Indian land holders would be secure.

From the 1850s until 1887, Native Americans in the interior West, like those across the United States, exchanged vast amounts of previously occupied land for the reservations on which they now reside; these exchanges were "federal diplomatic 'cover' for coerced and patently unfair Indian land cession agreements" (Cross 1998, p. 427). In addition, millions of acres of Indian timber were transferred by executive order into adjacent national forests and parks, and Native American people were banned from setting fires (Lewis 1995).

In 1887, Congress passed the General Allotment Act or Dawes Act, which caused substantial amounts of reservation lands held in trust to be divided into individual parcels. Every Indian living on the reservation at that time received a parcel based on their age and status, with surplus parcels sold to non-Indian settlers. Indians not living on a reservation or whose tribe was not assigned a reservation could apply for "surveyed or unsurveyed lands of the United States not otherwise appropriated" (General Allotment Act 1887, section 4; Monette 1995). However, all lands of the United States were already appropriated. The idea of the General Allotment Act was to minimize the American Indian land base, as well as to assimilate Indian people into white culture by encouraging them to engage in agriculture and ranching. The fragmentation of ownership includes beneficial ownership (as Indians communally), trust and fee ownership (as Indians individually (allotments)), and non-Indian fee land ownership (Cohen 1941, Getches et al. 1993). The General Allotment era, which ended in 1934 with the Indian Reorganization Act, set the stage for continual legal battles about tribal property and territory, and began the period of the "trust' doctrine (Getches et al. 1993, Cross 2003, Yazzie 2006). The trust doctrine was developed on the premise that the tribes were incompetent and unable to manage their resources and affairs with respect to property ownership. Most Indian lands are held in trust by the federal government for benefit of the tribe and allottees. Thus, the BIA of the United States Department of the Interior is charged with the management function of the trust responsibility.

\section{NATIVE AMERICANS, THE FEDERAL GOVERNMENT, AND TIMBER}

While Euro-American settlement was taking place and expanding westward, Native American people struggled to keep their traditional cultural integrity intact. Much of their landscape was changing because of Euro-American exploitation and trespass of both public and tribal timber, range, mineral, and water resources (Getches et al. 1993). In Wisconsin and Minnesota, extensive forests on Indian reservations were prime targets for exploitation by non-Indian timber industries (Godfrey 1996). As white pine, red pine (Pinus resinosa), and eastern white cedar (Thuja occidentalis) disappeared in the Lake States (Ryan 2006), timber corporations moved to easily accessible private and public domain in the West, and then to Indian timber (White 1992, Lewis 1995, Ryan 2006).

Federal law on Indian tribal timber has gone through three tortuous and distinct stages. The following sections briefly define the context of ownership and control of tribal timber: 1) a broad prohibition on the sale of Indian timber, 2) a restricted ability to sell dead timber, and 3) a restricted ability to sell any timber.

United States v. Cook (86 U.S. (19 Wall.) 591 1873), in 1873, marks the first case to decide the legal status of Indian timber. In United States v. Cook, the United States sued to recover possession of logs sold by Oneida Indians to a non-Indian, George Cook. The Court ruled that Indians had no more right to sell logs than to sell the land itself. The Circuit Court for the Eastern District of Wisconsin viewed Indian rights to reservation lands and to the timber upon it as rights of occupancy only. In United States $v$. Cook, the judges ruled:

The timber while standing is a part of the realty, and it can only be sold as the land could be. The land cannot be sold by the Indians and consequently the timber, until rightfully severed, cannot be ...

The timber was cut for sale and nothing else. Under such circumstances, when cut, it became the property of the United States 
absolutely, discharged of any rights of the Indians therein ...

To maintain his title under his purchase it is incumbent on the purchaser to show the timber was rightfully severed from the land. (86. U.S. (19 Wall.) at 593 1873.)

This narrow view was based on rulings in Johnson v. McIntosh and Cherokee Nation v. Georgia that fee title to tribal lands belongs to the United States.

In 1883, the approach of United States v. Cook was mirrored in the Act of 3 March, which provided among other things that "the proceeds of all pasturage and sales of timber, coal, or other products of any Indian reservation, shall be covered into the Treasury ..." (22 Stat. 590 (Code of Federal Regulations 25 U.S.C. $§ 197)$ ). As the Indians did not own the resources on the reservations, all revenue from those resources belonged to the United States and was properly deposited into the Treasury of the United States. Even after the General Allotment Act made the individualization of tribal or communal lands generally possible, the Attorney General of the United States determined that the rule of United States v. Cook also applied to Indian individuals' land allotments (United States $v$. Mitchell, 19 Op. Atty. Gen. 232 1889).

The Act of 7 June 1897 (30 Stat. 90 (Code of Federal Regulations 25 U.S.C. § 197) allowed Indian reservations in Minnesota to harvest and sell dead timber, whether standing or fallen. This authority was extended to other reservations by the Act of 16 February 1889 (25 Stat. 673 (Code of Federal Regulations 25 U.S.C. $\S 196)$. Both the 1897 and 1889 acts authorized the adoption of regulations by the Secretary of the Interior. One of the conditions that the Commissioner of Indian Affairs imposed on timber sales under these acts was that $10 \%$ of the gross proceeds derived from the sales should go to the stumpage or poor fund of the tribe, from which the old, sick, and otherwise helpless might be supported (Pine River Logging \& Improvement Co. v. United States 1902186 U.S. 279, 285). Thus, the regulations sought to ensure that the timber would provide some communal benefit, in addition to the individual employment opportunities created by these acts.

The 1889 Act met requirements of the NonIntercourse Act as to timber sales within its scope, and it led to many Indian timber sales as well as to widespread abuse in the Great Lakes region (Pine River Logging \& Improvement Co. v. United States 1902, Green v. Menominee Tribe 1914, and others). Pine and cedar in the Lake States was logged off public and Indian lands. Lumbermen took financial advantage of many tribes, with no federal oversight.

From the 1870 s to roughly 1890 , three national issues influenced the lumber industry and Wisconsin's Indian reservations. They were: (1) the development of federal regulations to sell Indian timber, (2) the prevention of development of federal regulations to sell Indian timber, and (3) the shift from reservation policy to allotment policy (Godfrey 1996). In 1888, Congress passed legislation to address the timber trespass on Indian reservations (Godfrey 1996).

In the Act of 25 June 1910 (Code of Federal Regulations 36 Stat. 858; 43 U. S. C. 148), Congress made a concerted effort to intensify the management and productivity of a wide variety of Indian properties and federal programs for Indians. The Act substantially amended the General Allotment Act of 1887, provided for heirship proceedings conducted by the Interior Department for deceased allottees, regulated wills made by Indians, tightened the criminal penalties for timber trespass or fire damage to Indian lands, authorized reserving Indian lands for reservoir and power purposes, and authorized allottees to lease their properties, among other provisions.

In 1911, the Interior Department promulgated detailed regulations for Indian forest management that were intended "to obtain the greatest revenue for the Indians consistent with a proper protection and improvement of the forests" (USDI Office of Indian Affairs 1911).

However, until the Indian Reorganization Act (IRA; 1934), both individual and tribal forest lands continued to suffer from timber trespass and abuse under the Act of 1910. The new legislation instead bridled the intensive use of Indian timber. Section 6 of the IRA provided:

The Secretary of the Interior is directed to make rules and regulations for the operations and management of Indian forestry on the principle of sustained-yield management, to restrict the number of livestock grazed on Indian range units to 
the estimated caring capacity of such ranges, and to promulgate such other rules and regulations as may be necessary to protect the range from deterioration, to prevent soil erosion, to assure full utilization of the range, and like purposes. (Code of Federal Regulations 25 U.S.C. $\S 466$; emphasis added.)

One of the key sponsors of the IRA, Representative Edgar Howard, explained that the sustained-yield requirement was intended to "assure that the Indian forests will be permanently productive and will yield continuous revenues to the tribes" (78 Cong. Rec. 11730 1934). With regard to Indian timber trespass, John Collier, the Commissioner of Indian Affairs, stated "we have to stop the slaughtering of Indian timber lands, to operate them on a perpetual yield basis and the bill expressly directs that this principle of conservation shall be applied throughout" (Hearings on H.R. 7902 before the House Committee on Indian Affairs, 73rd Cong., 2nd Sess. Part 1 at 35 1934).

It was not until the BIA began management of Indian forest lands (timber harvesting and management) that regulation and timber harvesting on Indian forest lands took place (Indian Timber Sales Act of 1964). The trust responsibility under the BIA is to regulate and oversee timber harvesting on Indian forest lands for production, development, and protection of tribal timber resources (United States v. Cook 1873, United States v. Shoshone Tribe of Indians 1938, Indian Timber Sales Act 1964). Pursuant to the Indian Timber Sales Act (1964), tribes were able to harvest timber on their reservations and the United States federal government began to allow more Indian tribal access to the benefits accruing from the sale of reservation timber (Yazzie 2006). Tribal timber corporations and government-managed timber sales brought a level of economic prosperity after World War II. However, the early efforts of the BIA and Forest Service officials to manage timber resources were directed at outlawing beneficial Indian fires in the fire-dependent landscapes of the West (Lewis 1973, White 1992, Lewis 1995, Godfrey 1996).

\section{TRUST RESPONSIBILITY, AND TRIBAL SELF-DETERMINATION AND GOVERNANCE OF OLD GROWTH: THE "MODERN" CONTEXT}

The National Indian Forest Resource Management Act (1990) and the Code of Federal Regulations (25 C.F.R. 163 et seq.) currently outline forest management in Indian country. In addition, the Tribal Forest Protection Act (2004) opens the door for stewardship agreements with adjacent federal agencies to reduce the threat of fire, insects, and disease to tribal lands. The National Forest Management Act (1976) does not regulate Indian forest lands or management. Tribal lands are not public lands and are held under the trust responsibility of the Federal government. There is a government-to-government relationship between federally recognized Indian tribes and the federal government. President G. W. Bush's Executive Memorandum in 2004 states:

The United States has a unique legal and political relationship with Indian tribes and a special relationship with Alaska Native entities as provided in the Constitution of the United States, treaties, and federal statutes. Presidents for decades have recognized this relationship. President Nixon announced a national policy of selfdetermination for Indian tribes in 1970. More recently, Executive Order 13175, entitled "Consultation and Coordination with Indian Tribal Governments," was issued in 2000. I reiterated my Administration's adherence to a governmentto-government relationship and support for tribal sovereignty and self-determination earlier this year in Executive Order 13336, entitled American Indian and Alaskan Native Education. (Bush 2004.)

Thus, each federal agency must have a process to ensure meaningful and timely input by tribal officials in the development of regulatory and other polices with substantial direct effects on one or more tribes, on the relationship between the federal government and tribes, or on distribution of power between the federal government and tribes.

In the Department of the Interior, the BIA's mission is "to enhance the quality of life, to promote economic opportunity, and to carry out the 
responsibility to protect and improve the trust assets of American Indians, Indian tribes and Alaska Natives" (Mission Statement of the Bureau of Indian Affairs). The BIA responsibility is the administration and management of 22.5 million ha (55.7 million acres) of land held in trust by the United States for American Indians, Indian tribes, and Alaska Natives. However, each federal agency shares in this trust responsibility.

Tribal people manage their landscape differently than public land or private land managers because the laws mandated through Congress differ in Indian country (Yazzie-Durglo 1998, Yazzie 2006). However, the principles of the Doctrine of Discovery remain evident in federal Indian law and in the self-determination era of the federal-Indian relationship in that the United States continues to have dominant control over tribal politics, commercial and real estate issues, and the sale or use of trust-allotted lands held by individual Indians (Cross 2003, Yazzie 2006). Despite the trust status, the most significant factor in tribal management is that tribal cultures and economies are motivated by a strong sense of connectivity to the land and ethical duty (Yazzie 2006) to protect their interests for the generations to come (Morishima 2006).

One can postulate that a similarity exists between the reduction of old-growth forests and the decline of Native American populations, which have been forced to assimilate, and the outlawing of their TEK practices, such as the use of fire.

Native American lands decreased in size from 56.7 million ha (140 million acres) in 1887 to 20.2 million ha (50 million acres) by 1934 (Cohen 1941, Monette 1995), with a checkerboard land ownership pattern on some reservations due to the General Allotment Act. Tribes now possess and manage about 6.5 million ha (16 million acres) of valuable tracts of forests land on 214 reservations in 23 states (Intertribal Timber Council 1993). Half of these acres are considered commercial timberlands, and the rest are woodlands (Intertribal Timber Council 1993). The percentage of old-growth forests on Indian reservations collectively is unknown, as is the percentage of old-growth forests on public lands. We do know that the expansion of the United States, which includes timber exploitation, intense overgrazing, and fire-suppression policies, dramatically reduced the quantity and quality of old-growth forests on both public and tribal landscapes.
The Indian Affairs Manual (USDI BIA 2006) states, "Indian forests are closely linked to the well being of Indian communities (53 IAM 2006, p. 3), and forest management must recognize the needs of the community along with other social and economic programs. Within the manual, the BIA ensures adequate forestry programs, and promotes direction for forest management polices and procedures. However, given the distinctive differences in Indian tribes, and unique differences in forest management, tribal membership concerns, etc., old-growth characteristics are undefined, and should remain so in Indian country.

\section{TRIBAL PERSPECTIVE ON OLD-GROWTH FORESTS: “GROWING GENERATIONS" AND SELF-DETERMINATION}

The difference in forest management in Indian country is that, at the heart of tribal cultures and other indigenous cultures of the United States, there is a strong bond between the health and welfare of the tribal people and the natural environment (Pecore 1992, Kimmerer and Lake 2001). Most Native Peoples understand that the environment is a blend of what is known as science and management (Pecore 1992, Yazzie-Pina and Covington 1994, Wolfey 1998, Yazzie 2006). Indeed, tribal communities have been preserved for centuries because of their knowledge of the natural, spiritual, and ecological world, and their understanding and respect for the interconnectedness between humans and all other living things (Moller et al. 2004). Additionally, tribal people possess a culture-based knowledge of ecosystems that has evolved and accumulated, and is continually tested and improved to maintain tribal existence (Kellert and Wilson 1993, Garibaldi and Turner 2004). The collection and use of this complex knowledge of the natural world is an integral part of any tribal decision-making process in the management of timber resources today (Pecore 1992, YazzieDurglo 1998, Yazzie 2006).

Baptiste Ritchie, a Lil'wat territory elder, gives an account of past fire use that maintained the forest habitat conditions that produced culturally important species in British Columbia:

If you go to burn then you get into trouble because the white men want to grow trees. Because they changed our ways they do good for us and we eat the food that the 
white men use. Then we forget the goodfood of our earliest forefathers. ... Now they have all disappeared because the hills grow weedy and no-one seems to tend them, noone clears them as our forefathers did so thoroughly. (Turner 1991, p. 62.)

Diné CARE (Citizens Against Ruining the Environment), an environmental activist group on the Navajo Nation, fought against and were instrumental in closing down the Navajo Forest Products Industry in the early 1990s. They described old growth as "grandfather" trees. However, old growth goes far beyond the physical appearance of older-aged trees that have specific diameter caps. Old growth can be associated with a combination of grandfather trees with an understory of multicohort recruitment trees to replace the aging grandfathers. As part of the Navajo philosophy, the health and well-being of the people is associated with the health and well-being of the environment. This includes living within the carrying capacity of the land, agriculturally and as a people, and may bring more equity in determining forest management for future generations. Forest management is essential to Navajo forestry, and preserving the forests only shows neglect and undermines Navajo conservation practices.

The perception of old growth was developed by the non-Indian community. Old-growth structure and condition were a product of Native American fireuse practice. The use of fire to maintain, cultivate, and enhance certain habitat conditions gave Native Peoples culturally important resources. Old-growth remnants are rare or gone in most forests, and most remaining forests today are second- or third-growth. The impetus for maintaining and restoring old growth is to satisfy the aesthetic, spiritual, cultural, and ecologic cravings of society today, and is a worthy goal.

\section{SUMMARY}

Since the arrival of European-Americans, Doctrine of Discovery principles have influenced and permeated American Indian laws, policies, traditions, and natural resources. The Doctrine of Discovery constitutes a double blow to indigenous rights because it validates the extension of foreign sovereign authority over indigenous peoples without their consent, violating the precepts of self- determination. The underlying impetus of the Doctrine was also to discriminate against indigenous people on the basis of race, preventing any legal security or stability on their communal lands and promoting the property rights of nonindigenous people. However, change is in the wind as promising avenues of self-determination and selfgovernance of tribal resources have begun to more strongly influence natural resource management and policy changes, and enhance trust responsibility.

Coupled with culture-based knowledge and tribal self-governance and determination (Indian SelfDetermination and Education Assistance Act 1975, amended 1988, Tribal Self-Governance Law 1994), tribes are now asserting their inherent right to selfgovernance to manage natural resources under the protection of the federal government's BIA and within the guidelines of sustained-yield management (National Indian Forest Resource Management Act 1990).

More importantly for Native American tribes, the land base remains an ancestral entity that is revered for the most part because of the importance of the memories it holds for their culture. Together with self-governance principles, Native American tribes can now tailor silvicultural treatments that reflect a cultural ethic, and restore and conserve old-growth structure while still satisfying economic needs (Yazzie 2006). Silvicultural strategies that foster multi-cohort stand structure and conserve large, tall, fire-adapted trees (which take longer to grow) may satisfy both short-term economic incentives and long-term biological and sociocultural considerations. Tribal control of silvicultural treatments can thus reflect the tribes' desires and enhance culturally important resources rather than those of the federal government.

Responses to this article can be read online at:

http://www.ecologyandsociety.org/voll2/iss $2 /$ art $21 /$ responses/

\section{LITERATURE CITED}

Anderson, M. K. 2005. Tending the wild: Native American knowledge and the management of California's natural resources. University of California Press, Ltd., Berkeley and Los Angeles, California, USA. 
Bush, G. W. 2004. Memorandum for the heads of Executive departments and agencies: governmentto-government relationship with tribal governments. White House, Office of the Press Secretary, Washington, D.C., USA. (online) URL: http://www .whitehouse.gov/news/releases/2004/09/20040923-4. html.

Cherokee Nation v. Georgia. 1831. 30 U.S. (5 Pet.) 1, 8 L.Ed. 25.

Code of Federal Regulations. 25 C.F.R. $\$ \S 163$ et seq.; § 196; § 197; § 466; and 36 Stat. 858; 43 U. S. C. 148

Cohen, F. S. 1941. Handbook of Federal Indian law. United States Government Printing Office, Washington, D.C., USA.

Cronon, W. 1983. Changes in the land: Indians, colonists, and the ecology of New England. Hill and Wang, New York, New York, USA.

Cross, R. 1998. Sovereign bargains, Indian takings, and the preservation of Indian country in the twentyfirst century. Arizona Law Review 40(425):

2003. The federal trust duty in an age of Indian self-determination: an epitaph for a dying doctrine? Tulsa Law Review 39(369):.

Delcourt, H. R., and P. A. Delcourt. 1997. Precolumbian Native American use of fire on southern Appalachian landscapes. Conservation Biology 11 (4):1010-1014.

Garibaldi, A., and N. Turner. 2004. Cultural keystone species: Implications for ecological conservation and restoration. Ecology and Society 9(3):1-18.

General Allotment Act. 1887. 24 Statute 388.

Getches, D. H., D. F. Wilkinson, and R. A. Williams, Jr. 1993. Federal Indian law. West Publishing Co., St. Paul, Minnesota, USA.

Godfrey, A. 1996. A forestry history of ten Wisconsin Indian reservations under the Great Lakes Agency: pre-contact to the present. United States Department of the Interior, Bureau of Indian Affairs, Branch of Forestry, Minneapolis Area Office, Minneapolis, Minnesota, USA.
Green v. Menominee Tribe of Indians in Wisconsin. 1914. 233 U.S. 558.

Indian Reorganization (Wheeler-Howard) Act. 1934. 25 U.S.C.A. $§ 461$ et seq.

Indian Self-Determination Act Amendments. 1994. Public Law No. 103-413, tit. 2, 108 Stat. 4250.

Indian Self-Determination and Education Assistance Act. 1975. 25 U.S.C. $\$ \$ 450$ et seq.; Title III, Public Law 93-638.

Indian Timber Sales Act. 1964. Public Law No. 88-301, 78 Stat. 186 (codified at 25 U.S.C. $\$ 407$ (1994).

Intertribal Timber Council (ITC). 1993. An assessment of Indian forests and forest management in the United States III-13. The Indian Forest Management Assessment Team, Portland, Oregon, USA.

Johnson v. McIntosh. 1823.21 U.S. (8 Wheat.) 543.

Kellert, S. R., and E. O. Wilson. 1993. The biophilia hypothesis. Island Press, Washington, D. C., USA.

Lewis, D. R. 1995. Native Americans and the environment: a survey of twentieth-century issues. American Indian Quarterly 19(3):423-477.

Lewis, H. T. 1973. Patterns of Indian burning in California: ecology and ethnohistory. Ballena Press, Ramona, California, USA.

Mettler, E. 1978. A unified theory of Indian tribal sovereignty. Hastings Law Journal 30:89-113.

Miller, R. 2005. The doctrine of discovery in American Indian law. Idaho Law Review 42(1):1122.

Moller, H., F. Berkes, P. O'Brian Lyver, and M. Kislalioglu. 2004. Combining science and traditional ecological knowledge: monitoring populations for co-management. Ecology and Society 9(3): 2. (online) URL: http://www.ecologya ndsociety.org/vol9/iss3/art2/.

Monette, R. A. 1995. Governing private property in Indian country: the double edge sword of the trust responsibility arising out of early Supreme Court 
decisions and the general allotment act. New Mexico Law Review 25:35, 39.

Morishima, G. 2006. A school of red herring. Evergreen Winter:17-20.

National Forest Management Act. 1976. 16 U.S.C. A. $\S \S 1601$ et seq. (partially revised in 1991).

National Indian Forest Resource Management Act. 1990. 25 U.S.C.A. $\$ \S 3101$ et seq.,; Public Law 101-603.; 104 Stat. 4532-4544.

Pecore, M. 1992. Menominee sustained-yield management: a successful land ethic in practice. Journal of Forestry 90(1):12-16.

Pevar, S. L. 1992. The rights of Indians and tribes. Second edition. Southern Illinois University Press, Carbondale, Illinois, USA.

Pine River Logging \& Improvement Co. v. United States. 1902. 186 U.S. 279.

Robertson, L. G. 2005. Conquest by law: how the discovery of Amrica disposessed indigenous peoples of their land. Columbia University, New York, New York, USA.

Ryan, J. C. 2006. Minnesota cedar. The Voice of the Timber Industry Timber Bulletin 62:30-33.

Simpson, L. R. 2004. Anti-colonial strategies for the recovery and maintenance of indigenous knowledge. American Indian Quarterly 28(34):373-382.

Stewart, O. 2002. Forgotten fires: Native Americans and the transient wilderness. University of Oklahoma Press, Norman, Oklahoma, USA.

Tribal Forest Protection Act. 2004. Public Law No. 108-278, H.R. 3846.

Tribal Self-Governance Law. 1994. Title IV, Pub. Law 93-638.; 108 Stat. 4250.

Turner, N. 1991. Burning mountain sides for better crops: aboriginal landscape burning in British Columbia. Archaeology in Montana 32(2):57-73.

United States v. Cook. 1873. 86 U.S. (19 wall. 591, 22 L.Ed. 210).
United States Department of the Interior (USDI) Bureau of Indian Affairs (BIA). 2006. 53 Indian Affairs manual, Chapter 1, Forestry, policies, authorities and responsibilities. 1.4 Scope. USDI, BIA, Washington, D.C., USA.

United States v. Mitchell. 1983. 463 U.S. 206; 1980. 445 U.S. 535.

United States Department of the Interior (USDI) Office of Indian Affairs. 1911. Regulations and Instructions for Officers in Charge of Forests on Indian Reservations. USDI Office of Indian Affairs, Washington, D.C., USA.

United States v. Shoshone Tribe of Wind River in Wyoming. 1938. 304 U.S. 111.

White, R. 1992. Indian land use and the National forests. Pages 173-179 in H. K. Steen, editor. Origins of the national forests: a centennial symposium. Forest History Society, Durham, North Carolina, USA.

Wilson, A. C. 1996. American Indian history or non-Indian perceptions of American Indian history. American Indian Quarterly 20(1):3-5.

Wolfey, J. 1998. Ecological risk assessment and management: their failure to value indigenous traditional ecological knowledge and protect tribal homelands. American Indian Culture and Research Journal 22(2):151-169.

Worchester v. Georgia. 1832. 31 U.S. (6 Pet.).

Yazzie, V. 2006. A cultural ethic in tribal forest management and self-determination: the human dimension of silviculture. Dissertation, University of Montana, Missoula, Montana, USA.

Yazzie-Durglo, V. 1998. The right to change tribal forest management. Journal of Forestry 96(11):3335 .

Yazzie-Pina, V., and W. W. Covington. 1994. Conservation biology, restoration ecology, and a Navajo view of nature. Pages 122-124 in W. W. Covington and L. F. DeBano, technical coordinators. Sustainable ecological systems: implementing an ecological approach to land management. U.S. Forest Service General Technical Report RM-247. 